\title{
Desain Pembangkit Listrik Tenaga Surya Apung untuk Wilayah Kepulauan Selayar, Sulawesi Selatan
}

\author{
Halida Aulia El Islamy, Wasis Dwi Aryawan \\ Departemen Teknik Perkapalan, Fakultas Teknologi Kelautan, Institut Teknologi Sepuluh Nopember (ITS) \\ e-mail:wasis@na.its.ac.id
}

\begin{abstract}
Abstrak - Pesatnya perkembangan industri di Indonesia masih menyisakan beberapa daerah terpencil dalam keadaan belum teraliri listrik, salah satunya yaitu Kabupaten Kepulauan Selayar, Sulawesi Selatan. Menanggapi hal tersebut, penggunaan energi terbarukan; energi panas matahari dapat dijadikan solusi kurangnya pemerataan pembangunan pembangkit listrik pada daerah terpencil tersebut. Dengan memanfaatkan kondisi geografis Kepulauan Selayar yang dikelilingi laut, hal tersebut dapat didesain Pembangkit Listrik Tenaga Surya Apung (PLTSA) yang terdiri dari barge dengan lambung katamaran sebagai media apung dari panel surya dan inverter sehingga nantinya satu PLTSA dapat memenuhi kebutuhan listrik pada beberapa kecamatan walaupun berada di pulau yang berbeda. Dengan menggunakan grid-tie system, pasokan listrik yang dihasilkan dapat langsung dialirkan ke grid PLN daerah setempat. Berdasarkan informasi dan kebutuhan listrik di Kabupaten Kepulauan Selayar, dibutuhkan sekitar 4 barge dengan 2410 unit panel surya dan 4 inverter pada tiap kapalnya untuk memenuhi kebutuhan daya listrik per hari sebesar 1.849.362,051 W. Ukuran utama kapal yang didapatkan adalah $L$ $=164 \mathrm{~m}, \mathrm{~B}=42 \mathrm{~m}, \mathrm{H}=4,2 \mathrm{~m}, \mathrm{~T}=1,2 \mathrm{~m}$. Dari ukuran utama kapal tersebut, didapatkan perhitungan analisis teknis, analisis ekonomis, analisis sensitivitas, serta gambar Lines Plan, General Arrangement, dan 3D Modeling.
\end{abstract}

Kata Kunci-Barge, Grid-tie system, Kabupaten Kepulauan Selayar, Katamaran, Panel Surya, Pembangkit Listrik Tenaga Surya Apung.

\section{PENDAHULUAN}

$\mathrm{D}$ ATA Kementerian ESDM, sebagaimana dapat diakses di situs webnya, menyebutkan terdapat 12.669 desa di negeri ini yang belum mendapat akses listrik. Bahkan 2.519 desa di antaranya masih gelap gulita. Di bagian selatan Sulawesi, terdapat kepulauan yang di dalamnya masih ditemukan desa-desa yang belum mendapatkan fasilitas listrik, baik dari negara maupun dari pembangkit sendiri. Salah satu daerah yang dimaksud belum mendapat akses listrik adalah desa-desa di Kepulauan Selayar, Sulawesi Selatan. Rasio elektrifikasi yang merupakan persentase rumah tangga yang sudah teraliri listrik dibandingkan dengan jumlah rumah tangga di Kepuluan Selayar adalah sebesar 61,34\% [1]. Hal tersebut menandakan bahwa masih ada $38,66 \%$ dari 33.041 rumah tangga yang rumahnya belum teraliri listik.

Untuk mengurangi jumlah rumah tangga yang belum teraliri listrik, dapat digunakan pembangkit listrik dengan menggunakan energi terbarukan seperti energi matahari. Oleh karena itu, pada jurnal ini akan dikembangkan tentang desain Pembangkit Listrik Tenaga Surya Apung dengan menggunakan grid-tie system serta memanfaatkan barge katamaran sebagai media apungnya, sehingga 1 pembangkit listrik tenaga surya apung dapat memasok listrik pada kecamatan-kecamatan yang berada di pulau yang berbeda.

\section{TINJAUAN PUSTAKA}

\section{A. Tinjauan Lokasi}

Kabupaten Kepulauan Selayar adalah sebuah kabupaten yang terletak di Provinsi Sulawesi Selatan, Indonesia. Kabupaten Kepulauan Selayar terdiri dari 2 sub area wilayah pemerintahan yaitu wilayah daratan yang meliputi kecamatan Benteng, Bontoharu, Bontomanai, Buki, Bontomatene, dan Bontosikuyu serta wilayah kepulauan yang meliputi kecamatan Pasimasunggu, Pasimasunggu Timur, Takabonerate, Pasimarannu, dan Pasilambena [2].

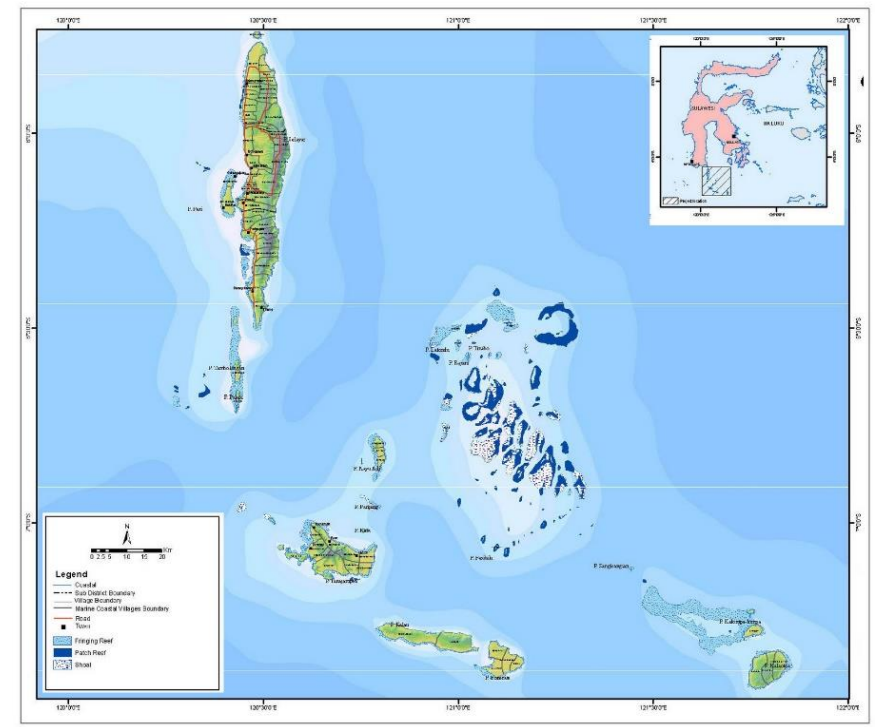

Gambar 1. Kepulauan Selayar

Menurut Infrastruktur Ketenagalistrikan, di Kabupaten Kepulauan Selayar sendiri belum terdapat pembangkit listrik yang beroperasi, jaringan listrik yang beroperasi di atas $70 \mathrm{kV}$ atau yang masih direncanakan, gardu induk dengan $70 \mathrm{kV}$ yang beroperasi atau masih direncanakan. Baru terdapat 1 (satu) perencanaan PLTU (Pembangkit Listrik Tenaga Surya) tepatnya di kecamatan Bontomatene [3].

Peta Rencana Kelistrikan Interkoneksi Sulawesi 2016 dalam Rencana Usaha Penyediaan Tenaga Listrik PLN 2017-2026, masih belum terlihat adanya perencanaan sistem yang akan dibanguun di Kabupaten Kepulauan Selayar [4]. 


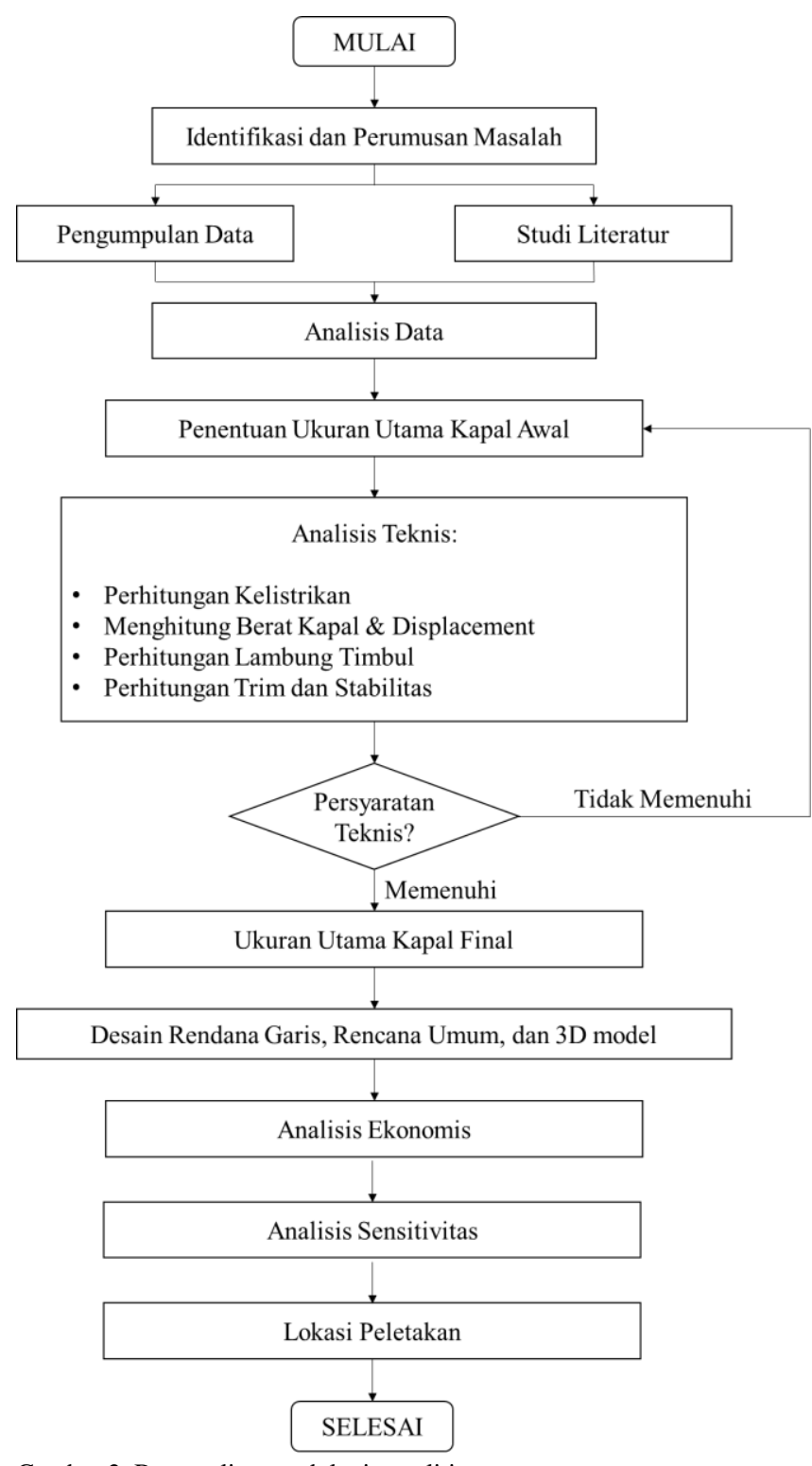

Gambar 2. Bagan alir metodologi penelitian.

\section{B. Floating Power Plant}

Powership (atau pembangkit listrik terapung) merupakan kapal dengan tujuan khusus, dimana pembangkit listrik dipasang di atas barge sebagai sumber daya pembangkit listrik Powership (pembangkit listrik terapung) memiliki sejumlah keunggulan dibandingkan pembangkit listrik lain yang ada di darat [5] antara lain:

- Mampu menyediakan suplai listrik pada dareah dengan ketersediaan lahan yang kecil dan infrastruktur minim

- Merupakan aset yang dapat dipindahkan dan dijual

- Tidak tergantung pada kualitas tanah

- Tetap dapat menyediakan suplai listrik yang stabil bahkan saat banjir atau gempa bumi

\section{Grid-Tie System}

Sistem fotovoltaik terikat dengan grid adalah sistem yang terdiri dari panel surya listrik, inverter dasi grid, baterai atau tidak ada baterai yang terhubung langsung ke grid (catatan: jika tidak menggunakan baterai, maka sistem tidak bekerja ketika grid turun bahkan saat terdapat sinar matahari.

Sistem ini memungkinkan para pemilik sistem untuk menjual energi mereka ke jaringan utilitas melalui kebijakan yang sudah ada sebagai metering bersih. Misal, jika selama waktu yang diberikan suatu sistem tenaga memakan $500 \mathrm{kWh}$ ke dalam grid dan menggunakan $100 \mathrm{kWh}$ dari grid, maka sistem akan menerima kompensasi sebesar $400 \mathrm{kWh}$ [6].

\section{Barge Katamaran}

Barge kapal besar dengan alas yang rata. Kapal ini membawa muatan berat dari satu tempat ke tempat lain. Barge tidak dapat bergerak sendiri, melainkan membutuhkan push boat untuk mengatur barge ke atas dan ke bawah selama di sungai dan kanal, juga tugboat untuk menarik barge [7].

Katamaran adalah kelas kapal yang memiliki dua lambung. Umumnya kedua lambung tersebut dalam ukuran yang sama. Lambung dihubungkan oleh struktur semacamnya. Luas geladak dari katamaran lebih luas dibandingkan dengan monohull volume benaman dan luas permukaan basah kecil, serta stabilitas yang lebih baik karena memiliki dua lambung [8].

\section{METODOLOGI PENELITIAN}

Diagram alir (flowchart) metodologi dalam pengerjaan Jurnal ini dapat dilihat pada Gambar 2.

\section{ANALISIS TEKNIS DAN PEMBAHASAN}

Pembangkit Listrik Tenaga Surya Apung atau Floating Solar Power Plant (FSPP) ini nantinya akan digunakan untuk memasok kekurangan listrik di Kabupaten Kepulauan Selayar dengan kelebihan FSPP ini dapat memasok listrik pada kecamatan-kecamatan yang ada di beberapa pulau..

\section{A. Perhitungan Kebutuhan Listrik}

Kebutuhan listrik dihitung dengan melakukan persamaan dari data persentase rumah tangga yang menggunakan menggunakan listrik PLN sebagai sumber penerangan pada tahun 2016 dengan besar listrik PLN yang terjual pada tahun 2016 [1].

Tabel 1.

Perbandingan Kebutuhan Listrik

\begin{tabular}{lcc}
\hline \hline \multicolumn{1}{c}{$\begin{array}{c}\text { Jenis Sumber } \\
\text { Penerangan }\end{array}$} & $\begin{array}{c}\text { Persentase Sumber } \\
\text { Penerangan }\end{array}$ & $\begin{array}{c}\text { Listrik yang Diproduksi } \\
(\mathrm{kWh})\end{array}$ \\
\hline Listrik PLN & $57,93 \%$ & 28.880 .165 \\
Bukan Listrik & $6,77 \%$ & $3.375 .085,74$ \\
\hline \hline
\end{tabular}

Untuk menggantikan sumber penerangan bukan listrik dibutuhkan energi listrik sebesar 3.228.996,67 kWh, dengan asumsi lama penyinaran selama 5 jam [9], sehingga daya listrik yang diperlukan adalah sebesar $675.017,15 \mathrm{~kW}$ per tahun. FSPP yang rencananya akan dibangun adalah sejumlah 4 barge, sehingga per barge FSPP diperlukan untuk menghasilkan minimal 462.340,51 W per harinya.

\section{B. Penentuan Panel Surya dan Inverter}

Panel surya dan inverter yang dipilih adalah yang dapat diaplikasikan untuk grid-tie system. Dengan besar daya maksimal panel surya sebesar $345 \mathrm{~W}$ dan efisiensi sebesar 
17,8\%, dibutuhkan minimal 2.155 unit panel surya untuk 1 FSPP.

Panel surya dengan ukuran 1.956 x 991 x $45 \mathrm{~mm}$ rencana dipasang dengan susunan sebagai berikut sebagai berikut:
Jumlah panel per baris
$=54$ panel
Jumlah baris
$=44$ baris
Sudut kemiringan pemasangan panel $=15^{\circ}$
Jarak antar panel
$=0,05 \mathrm{~m}$
Lebar jalan antar baris
$=0,6 \mathrm{~m}$
Lebar jalan tengah
$=1 \mathrm{~m}$

sehingga didapatkan 2.410 panel surya per FSPP dan 4 inverter dengan input DC sebesar $220 \mathrm{~kW}$ untuk mengubah arus listrik dari panel surya.

\section{Penentuan Ukuran Utama}

Ukuran utama awal kapal didapatkan dengan cara membuat lay out awal dari FSPP yang dibuat atas dasar luasan minimal dari susunan panel surya yang digunakan [10] sehingga didapatkan luas minimum dari geladak kapal sebesar:

Lebar barisan panel $=37,008 \mathrm{~m}$

Panjang barisan panel $=159,973 \mathrm{~m}$

Setelah didapatkan luasan geladak, dengan metode point base didapatkan ukuran utama kapal yang disesuaikan dengan persyaratan teknis [11];

$$
\begin{array}{llll}
\mathrm{B}_{1} & =42 \mathrm{~m} & & \mathrm{~B}_{2}=24 \mathrm{~m} \\
\mathrm{~L} & =164 \mathrm{~m} & & \mathrm{H}=4,2 \mathrm{~m} \\
\mathrm{~T} & =1,2 \mathrm{~m} & &
\end{array}
$$

\section{Perhitungan Listrik yang Dihasilkan}

Dari jumlah final panel surya dan inverter yang digunakan, dalam sehari FSPP dapat menghasilkan 2.881,473 kWh energi listrik atau 720,37 kW daya listrik.

\section{E. Perhitungan Koefisien Bentuk Badan Kapal}

Setelah didapatkan ukuran utama kapal, langkah selanjutnya yang dilakukan adalah melakukan perhitungan awal. Yang meliputi perhitungan koefisien $(\mathrm{Cb}, \mathrm{Cm}, \mathrm{Cp}$, dan $\mathrm{Cwp})$ serta displacement.

$$
\begin{aligned}
& \mathrm{C}_{\mathrm{B}}=0.83 \\
& \mathrm{C}_{\mathrm{M}}=0.884 \\
& \mathrm{C}_{\mathrm{P}}=0.939 \\
& \mathrm{C}_{\mathrm{WP}}=1 \\
& \mathrm{~V}=2350.14 \mathrm{~m}^{3} \\
& \Delta \quad=2409 \text { ton }
\end{aligned}
$$

\section{F. Perhitungan Berat Kapal}

Berat kapal terdiri dari 2 komponen, yaitu komponen DWT (Dead Weight tonnage) dan komponen LWT (Light Weight tonnage).

Tabel 2.

\begin{tabular}{ccc}
\multicolumn{3}{c}{ Rangkuman Perhitungan Berat Kapal } \\
\hline Keterangan & Nilai & Satuan \\
\hline DWT & 12.87 & ton \\
LWT & 2345.24 & ton \\
Berat & 2359.711 & ton \\
Displacement & 2409 & ton \\
Selisih & 49 & ton \\
Margin & $2.05 \%$ & ton \\
\hline \hline
\end{tabular}

\section{G. Perhitungan Titik Berat Kapal}

Perhitungan titik Berat Kapal terdiri dari titik berat DWT dan titik berat LWT.

$$
\begin{aligned}
& \mathrm{LCG}=0,210 \mathrm{~m} \text { dari Midship } \\
& \mathrm{VCG}=2,668 \mathrm{~m} \text { dari Baseline }
\end{aligned}
$$

\section{H. Perhitungan Freeboard}

Perhitungan freeboard FSPP menggunakan persyaratan freeboard yang tertera pada tabel freeboard standar ICLL 1966 [12] sesuai dengan tipe kapal tipe kapal A dengan panjang 164 $\mathrm{m}$. Berikut ini merupakan koreksi-koreksi freeboard.

Tabel 3.

Rangkuman Perhitungan Freeboard

\begin{tabular}{lcc}
\hline \hline \multicolumn{1}{c}{ Lambung Timbul } & Nilai & Satuan \\
\hline Lambung Timbul yang Syaratkan & 1,64 & $\mathrm{~m}$ \\
Lambung Timbul Sebenarnya & 3,00 & $\mathrm{~m}$ \\
Kondisi & Diterima & \\
\hline
\end{tabular}

\section{Perhitungan Trim}

Trim maksimal menurut SOLAS Reg II/7 [13] yaitu 0.5\% Lwl. Berikut ini adalah hasil perhitungan trim.

Tabel 4.

Rangkuman Perhitungan Trim

\begin{tabular}{ccc}
\hline \hline Batasan & Nilai & Status \\
\hline 0,758 & $-0,015$ & Diterima \\
\hline \hline
\end{tabular}

\section{J. Perhitungan Stabilitas}

Kriteria stabilitas untuk kapal. Pada kasus ini kriteria yang digunakan adalah IMO MSC.36(63) HSC Code Multihull Annex 7 [14].

Tabel 5.

Rangkuman Perhitungan Stabilitas

\begin{tabular}{lccc}
\hline \hline \multicolumn{1}{c}{ Criteria } & Nilai & Satuan & Status \\
\hline Area 0 to 30 & m.deg & 1.527 .513 & Pass \\
Angle of Maximum GZ & $\mathrm{deg}$ & 13,6 & Pass \\
\hline \hline
\end{tabular}

\section{K. Pembuatan Rencana Garis}

Setelah semua perhitungan selesai, langkah selanjutnya adalah pembuatan Rencana Garis atau Lines Plan.

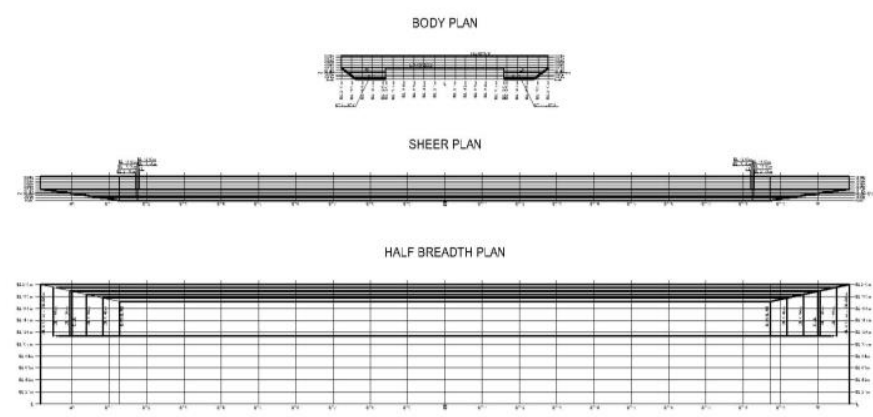

Gambar 3. Lines Plan

\section{Pembuatan Rencana Umum}

Penyusunan rencana umum merupakan suatu proses bertahap yang disusun dari percobaan, dan pengecekan, seperti pada Gambar 4. 

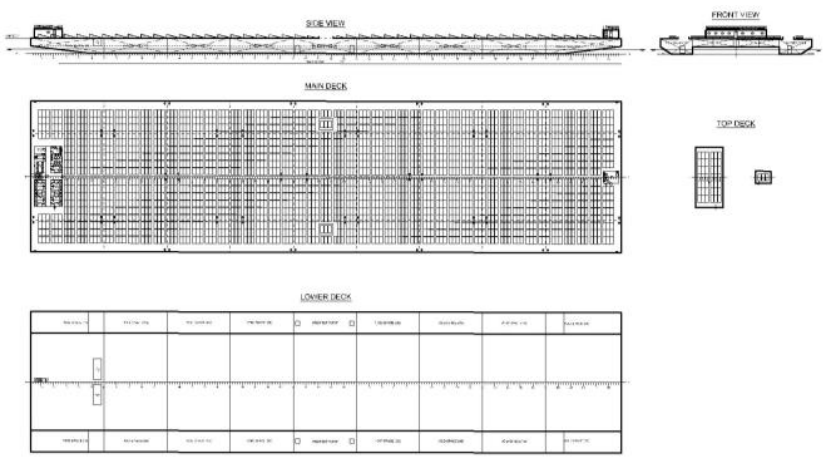

Gambar 4. General Arrangement

\section{Gambar 3D}

Pembuatan desain 3D dilakukan untuk mengetahui bentuk kapal dalam 3 dimensi.

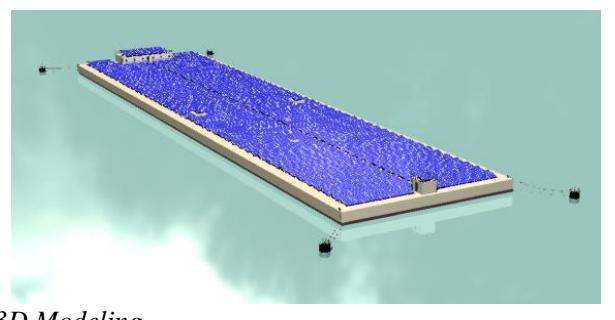

Gambar 5. 3D Modeling.

\section{N. Lokasi Penempatan FSPP}

Dari 4 FSPP yang ada, rencananya akan diletakkan di 4 titik untuk memasok listrik pada kecamatan-kecamatan yang belum sepenuhnya teraliri listrik;

Gambar 6. Peletakan FSPP.

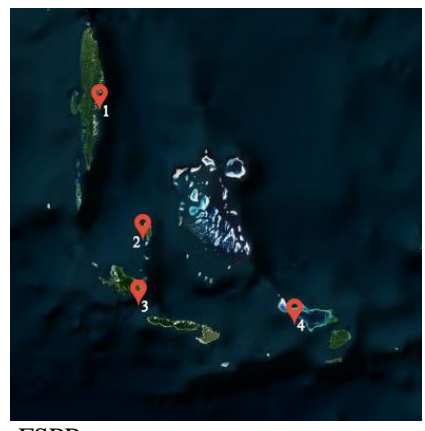

Di mana

1. FSPP 1 memasok listrik untuk kecamatan Bontomantene, Bontomanai, Bontoharu, dan Bontosikuyu.

2. FSPP 2 memasok listrik untuk kecamatan Takabonerate.

3. FSPP 3 memasok listrik untuk kecamatan Pasimassunggu dan Pasimassunggu Timur.

4. FSPP 4 memasok listrik untuk kecamatan Pasimarannu dan Pasilambena.

\section{ANALISIS EKONOMIS}

\section{A. Biaya Pembangunan}

Biaya pembangunan kapal terdiri dari weight cost (biaya baja kapal, peralatan, dan perlengkapanc kapal) dan non weight cost serta koreksi biaya pembangunan [15]. Setelah dihitung didapatkan biaya pembangunan sebesar Rp 27.560.846.888,92

\section{B. Biaya Operasional}

Biaya operasional FSPP adalah sebesar Rp 3.631.301.627 per tahun.

\section{Harga Listrik}

Harga listrik ditentukan sesuai dengan Permen ESDM No. 12 Tahun 2017 Bagian Kedua Pasal 5 tentang Pembelian Tenaga Listrik dari PLTS Fotovoltaik. Dalam kasus ini, BPP Pembangkitan Sulawesi Selatan Tahun 2018 adalah sebesar Rp. 2.043 per $\mathrm{kWh}$, sehingga estimasi harga jual listrik adalah sebesar Rp 1.736,55 per kWh.

\section{Harga Sewa FSPP}

Harga Penyewaan FSPP ditentukan dengan melihat kelayakan investasi guna menutupi pengeluaran untuk biaya operasional dan mendapatkan untung.

\section{ANALISIS SENSITIVITAS}

Proyek pembangunan FSPP ini dinilai dengan melihat kelayakan kegiatan investasi dari hasil analisis pada 3 kondisi dengan 3 variasi bunga bank dan 7 variasi IRR dalam waktu 25 tahun. Hasil perhitungan dari ketiga kondisi tersebut nantinya juga akan digunakan untuk memnentukan harga jual FSPP serta subsidi yang dibutuhkan untuk menutupi kurangnya dana untuk mendapatkan untung pada IRR tertentu sebesar selisih antara harga sewa FSPP dengan harga penjualan listrik per tahun.

A. Kondisi 1: Bunga Bank sebesar 8\% dengan variasi IRR: $4 \%, 6 \%, 8 \%, 10 \%, 12 \%, 14 \%$, dan $16 \%$.

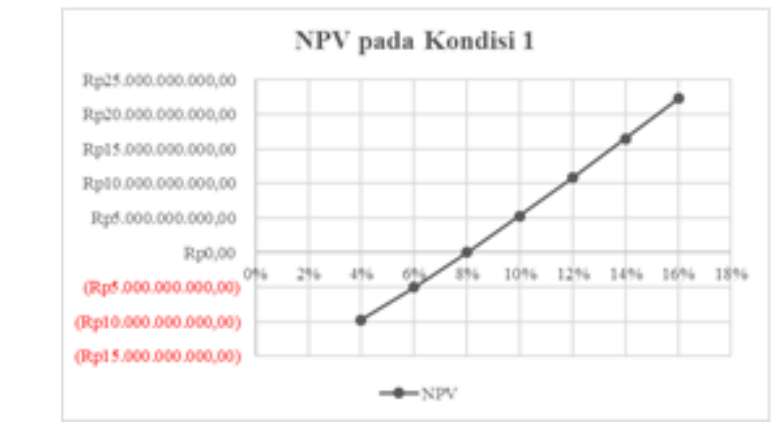

Gambar 7. Grafik NPV pada Kondisi 1.

Tabel 6.

Rangkuman Perhitungan Analisis Sensitivitas pada Kondisi 1

\begin{tabular}{cccc}
\hline \hline IRR & NPV & Harga Sewa FSPP & Status \\
\hline $4 \%$ & $($ Rp9.752.665.139,40) & Rp6.730.733.246 & Proyek Ditolak \\
$6 \%$ & $($ Rp5.044.494.120,37) & Rp7.318.807.530 & Proyek Ditolak \\
$8 \%$ & $($ Rp585,58) & Rp7.948.890.190 & Proyek Ditolak \\
$10 \%$ & Rp5.314.422.077,04 & Rp8.612.688.359 & Proyek dapat Dijalankan \\
$12 \%$ & Rp10.837.203.966,63 & Rp9.302.511.645 & Proyek dapat Dijalankan \\
$14 \%$ & Rp16.514.984.716,62 & Rp10.011.695.069 & Proyek dapat Dijalankan \\
$16 \%$ & Rp22.303.949.048,02 & Rp10.734.765.883 & Proyek dapat Dijalankan \\
\hline \hline
\end{tabular}

Pada NPV = 0, IRR yang didapatkan adalah sebesar 8,000 $\%$, untuk mendapatkan keuntungan, dapat diambil keputusan 
dengan memilih di antara harga sewa FSPP yang memliki besar IRR > bunga bank dengan NPV > 0 .

B. Kondisi 2: Bunga Bank sebesar 10\% dengan variasi IRR: $4 \%, 6 \%, 8 \%, 10 \%, 12 \%, 14 \%$, dan $16 \%$

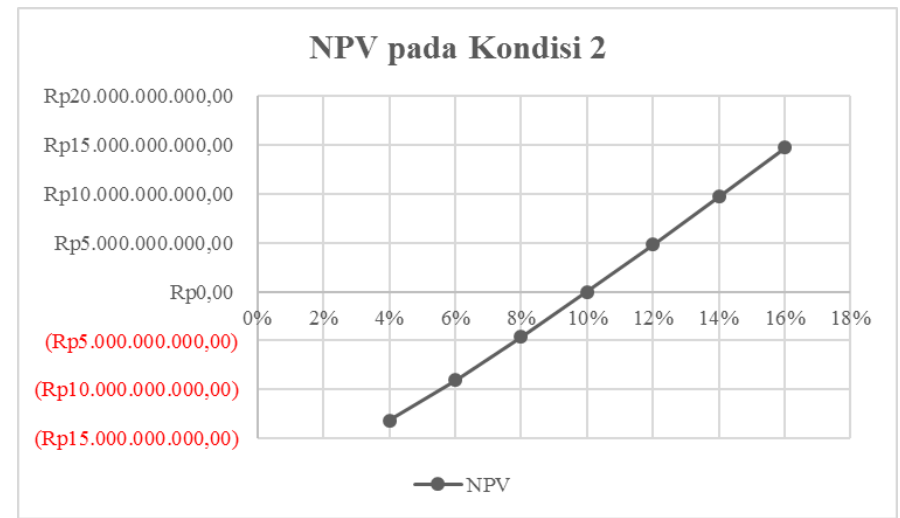

Gambar 8. Grafik NPV pada Kondisi 2

Tabel 7.

Rangkuman Perhitungan Analisis Sensitivitas pada Kondisi 2

\begin{tabular}{cccc}
\hline \hline IRR & NPV & Harga Sewa FSPP & Status \\
\hline $4 \%$ & $(\mathrm{Rp} 13.148 .707 .848,31)$ & Rp6.881.241.480 & Proyek Ditolak \\
$6 \%$ & $(\mathrm{Rp} 9.027 .065 .894,92)$ & Rp7.486.672.611 & Proyek Ditolak \\
$8 \%$ & $(\mathrm{Rp} 4.624 .784 .230,58)$ & Rp8.133.327.123 & Proyek Ditolak \\
$10 \%$ & Rp2.214,19 & Rp8.812.665.532 & Proyek dapat Dijalankan \\
$12 \%$ & Rp4.793.927.746,39 & Rp9.516.848.911 & Proyek dapat Dijalankan \\
$14 \%$ & Rp9.711.220.466,45 & Rp10.239.153.790 & Proyek dapat Dijalankan \\
$16 \%$ & Rp14.714.651.480,62 & Rp10.974.111.589 & Proyek dapat Dijalankan \\
\hline \hline
\end{tabular}

Pada NPV = 0, IRR yang didapatkan adalah sebesar 9,999\%, untuk mendapatkan keuntungan, dapat diambil keputusan dengan memilih di antara harga sewa FSPP yang memliki besar IRR > bunga bank dengan NPV > 0 .

C. Kondisi 3: Bunga Bank sebesar $12 \%$ dengan variasi IRR: $4 \%, 6 \%, 8 \%, 10 \%, 12 \%, 14 \%$, dan $16 \%$

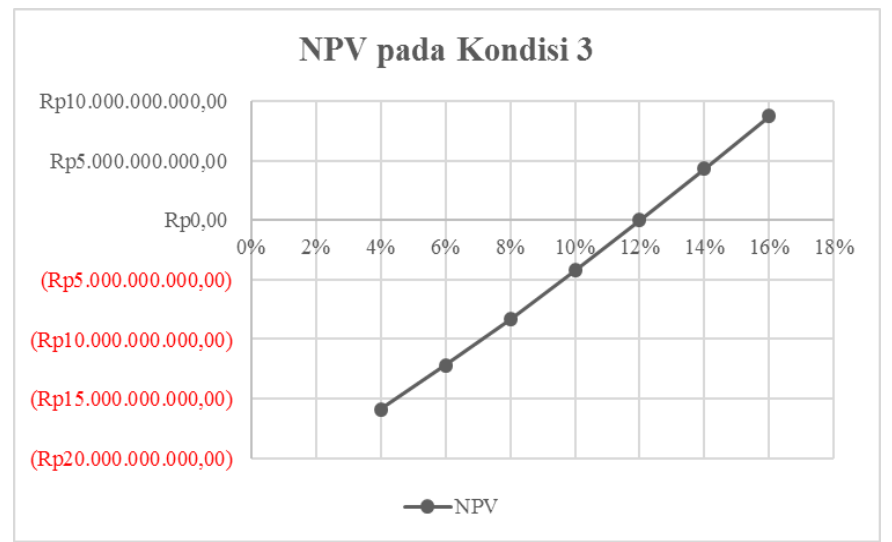

Gambar 9. Grafik NPV pada Kondisi 3.

Tabel 8.

Rangkuman Perhitungan Analisis Sensitivitas pada Kondisi 3

\begin{tabular}{cccc}
\hline \hline IRR & NPV & Harga Sewa FSPP & Status \\
\hline $4 \%$ & $(\mathrm{Rp} 15.879 .046 .319,00)$ & Rp7.031.749.345 & Proyek Ditolak \\
$6 \%$ & $(\mathrm{Rp} 12.215 .590 .915,45)$ & $\mathrm{Rp7} .654 .536 .616$ & Proyek Ditolak \\
$8 \%$ & $(\mathrm{Rp} 8.314 .248 .557,88)$ & $\mathrm{Rp} 8.317 .764 .660$ & Proyek Ditolak \\
$10 \%$ & $(\mathrm{Rp} 4.226 .730 .038,43)$ & $\mathrm{Rp} 9.012 .642 .643$ & Proyek Ditolak \\
$12 \%$ & $\mathrm{Rp1} .672,23$ & $\mathrm{Rp} 9.731 .186 .864$ & Proyek Ditolak \\
$14 \%$ & $\mathrm{Rp} 4.326 .032 .497,25$ & Rp10.466.611.930 & Proyek dapat Dijalankan \\
$16 \%$ & Rp8.s719.244.970,26 & Rp11.213.457.874 & Proyek dapat Dijalankan \\
\hline \hline
\end{tabular}

Pada NPV = 0, IRR yang didapatkan adalah sebesar $12,068 \%$, untuk mendapatkan keuntungan, dapat diambil keputusan dengan memilih di antara harga sewa FSPP yang memliki besar IRR $>$ bunga bank dengan NPV $>0$.

\section{KESIMPULAN}

Setelah dilakukan percobaan dan penelitian maka kesimpulan dari Tugas Akhir ini adalah sebagai berikut:

1. Dibutuhkan 3.375.085,74 kWh energi listrik atau $675.017,15 \mathrm{~W}$ daya listrik untuk memasok listrik bagi rumah tangga yang belum teraliri listrik di Kabupaten Kepulauan Selayar per tahun. Dari 4 FSPP yang rencana dibangun, 1 FSPP minimal dapat menghasilkan 462.340,51 W per hari.

2. Dari besar daya listrik minimal yang dihasilkan 1 FSPP, didapatkan jumlah minimal panel surya yang akan digunakan. Ukuran utama FSPP ditentukan berdasarkan susunan panel surya yang diletakkan di atas geladak dengan membuat layout awal kemudian didapatkan ukuran utama FSPP yang memenuhi dengan persyaratan teknis kapal, yaitu:

$$
\begin{array}{ll}
\text { LOA }=164 & \mathrm{~m} \\
\mathrm{~B}_{1}=42 & \mathrm{~m} \\
\mathrm{~B}_{2}=24 & \mathrm{~m} \\
\mathrm{H}=2,4 & \mathrm{~m} \\
\mathrm{~T}=1,2 & \mathrm{~m}
\end{array}
$$

3. Desain Lines Plan, General Arrangement, dan 3D Model telah dibuat.

4. Dengan menggunakan grid-tie system; 2410 unit panel surya dan 4 unit inverter, dihasilkan $2.482,377 \mathrm{kWh}$ energi listrik atau $620,59 \mathrm{~kW}$ daya listrik yang dapat langsung disalurkan ke grid PLN tiap harinya. Jumlah listrik yang dihasilkan 4 FSPP tiap harinya yaitu sebesar 9.929,508 $\mathrm{kWh}$ atau 2.482.377 $\mathrm{W}$, dapat memenuhi kekurangan listrik yang ada di Kabupaten Kepulauan Selayar.

5. Harga listrik per kWh sesuai dengan Permen ESDM No. 12 Tahun 2017 sebesar Rp 1.736,55 per kWh.

6. Berdasarkan Analisis Sensitivitas, dari 3 (tiga) kondisi Bunga Bank $(8 \%, 10 \%$, dan 12\%) dengan 7 (tujuh) variasi IRR $(4 \%, 6 \%, 8 \%, 10 \%, 12 \%, 14 \%, 16 \%)$ didapatkan 21 gambaran kelayakan investasi proyek sebagai pertimbangan dalam pemilihan harga sewa FSPP serta subsidi yang diperlukan.

7. Dari 4 FSPP yang ada, direncanakan akan diletakkan di 4 titik yaitu; FSPP ke-1 untuk memasok listrik untuk kecamatan Bontomantene, Bontomanai, Bontoharu, dan Bontosikuyu; FSPP ke-2 untuk memasok listrik untuk kecamatan Takabonerate; FSPP ke-3 untuk memasok listrik untuk kecamatan Pasimassunggu dan Pasimassunggu Timur; FSPP ke-4 untuk memasok listrik untuk kecamatan Pasimarannu dan Pasilambena.

\section{DAFTAR PUSTAKA}

[1] Badan Pusat Statistika, "Kabupaten Kepulauan Selayar Dalam Angka 2017," Kepulauan Selayar, 2017.

[2] P. Selayar, "Sejarah Selayar," Kepulauan Selayar, 2016.

[3] Gis.den.go.id, "DEN dari Infrastruktur Ketenagalistrikan," 2018.

[4] Kementrian Energi dan Sumber Daya Mineral, "Nomor 12 Tahun 2017 Pemanfaatan Sumber Energi Terarukan untuk Penyediaan 
Tenaga Listrik," 2017.

[5] L. Saputro and W. Aryawan, "Desain Barge Pembangkit Listrik Tenaga Konversi Panas Air Laut untuk Wilayah Kepulauan Talaud, Sulawesi Utara," Surabaya, 2016.

[6] M. Boxwell, Solar Electricity Handbook. Birmingham: Greenstream Publishing Ltd, 2017.

[7] K. Chopra, "What is an Offshore Barge," Marine Insight, 2015. .

[8] A. Romadlon, "Perancangan Kapal Katamaran Pariwisata di Pulau Menjangan Besar - Karimunjawa," Semarang.

[9] H. Hasan, "Perancangan Pembangkit Listrik Tenaga Surya di Pulau Saugi," J. Ris. dan Teknol. Kelaut., 2012.

[10] D. Hariyanto and H. A. Kurniawati, "Desain Power Plant Barge 20 MW Tenaga Gas sebagai Unit Pembantu Wilayah Kabupaten Kepulauan Selayar Sulawesi Selatan,” Surabaya, 2015.
[11] D. A. Puspitasari and W. Aryawan, "Desain Floatin Power Plant dengan Tenaga Panel Surya untuk Masyarakat Maluku Utara," Surabaya, 2018.

[12] IMO, International Convention on Load Lines. London: Lloyd's Register, 1966.

[13] I. M. O. (IMO), International Convention for the Safety of Life at Sea, 1974, as amended (SOLAS 1974). London: IMO Publishing, 2009.

[14] IMO, "Intact Stability (IS) Code-Intact Stability for HSC Multihull."

[15] D. Agustin and H. Kurniawati, "Desain Kapal Motor Penyebrangan dengan Sistem Penggerak Hibrida untuk Rute Ujung SurabayaKamal Bangkalan," Surabaya, 2017. 